Vol. 12, No. 1 (June 2020)

\title{
Pemikiran Pendidikan Ibnu Khaldun
}

\author{
Ina Zainah Nasution*1 \\ Universitas Muhammadiyah Sumatera Utara*1 \\ ${ }^{*}$ email:inazainah@umsu.ac.id
}

Abstract

Ibnu Khaldun was the greatest Muslim scientist of his time. His thoughts are futuristic and still be used for today. As a recognized scientist both in the West and in the East, we should take the wisdom points of his thinking in the field of education. Ibnu Khaldun set educational goals that are free from materialistic elements, an integrated curriculum and even holistic teaching and learning methods. Khaldun's view later in the 20th century, along with the development of contemporary learning psychology, we know him with the term gestalt psychology which was introduced by Wolfgang Kohler in 1912 in Germany. Khaldun's three steps in the delivery of teaching material are also in accordance with the theory issued by Kohlerberg about the maturity of one's cognition affecting one's ability to receive things. Therefore, to make closer to the true concept of Ibn Khaldun's education, the writer uses the method of content research which is to make Ibn Khaldun's monumental work: The Muqaddimah as the main reference and several other supporting books. So with this effort we can know that Ibn Khaldun was truly "the great Muslim thinker" whose idea in the field of education is very inspiring and even continue to be used for today. Another idea that is even used as a trend in the world of education today is the study tour learning method (rihlah) and homeschooling (sekolah rumah) and it's curriculum. Nowadays, Khaldun's bright ideas in the world of education, along with the methods he offered that were global and holistic, are still being used. That's becoming clear evidence that Ibn Khaldun was a great thinker throughout history.

Keywords: Educational Ideas, Educational Philosophy of Ibn Khaldun.

\section{Artikel Info}

Received:

18 March 2020

Revised:

27 March 2020

Accepted:

20 April 2020

Published:

04 June 2020 


\section{Abstrak}

Ibnu Khaldun merupakan ilmuwan muslim terbesar di masanya. Pemikiran-pemikirannya bersifat futuristik dan masih dapat dipergunakan hingga saat ini. Sebagai ilmuwan yang diakui baik di Barat maupun di Timur, sepatutnya kita mengambil butir-butir hikmah pemikirannya di bidang pendidikan. Ibnu Khaldun menetapkan tujuan-tujuan pendidikan yang terbebas dari unsur materialistik, kurikulum yang terintegrasi bahkan metode mengajar dan belajar yang holistik. Pandangan Khaldun ini kelak pada abad ke-20, seiring dengan perkembangan psikologi belajar kontemporer, kita mengenalnya dengan istilah psikologi gestalt yang diperkenalkan oleh Wolfgang Kohler pada tahun 1912 di Jerman. Tiga langkah Khaldun dalam penyampaian materi ajar juga sesuai dengan teori yang dikeluarkan oleh Kohlerberg tentang usia kematangan kognisi seseorang mempengaruhi kemampuannya menerima sesuatu. Oleh karena itu, untuk mendekatkan kita dengan konsep pendidikan Ibnu Khaldun yang sebenarnya, penulis menggunakan metode content research yaitu menjadikan karya monumental Ibnu Khaldun: The Muqaddimah sebagai referensi utama dan beberapa buku pendukung lainnya. Sehingga dengan upaya ini dapat kita ketahui bahwa Ibnu Khaldun benar-benar "the great muslim thinker" yang gagasannya dalam bidang pendidikan sangat menginspirasi bahkan masih terus dipergunakan sampai saat ini. Gagasan lainnya yang bahkan dijadikan trend dalam dunia pendidikan sekarang ini adalah metode belajar study tour (rihlah) dan homeschooling (sekolah rumah) berikut kurikulumnya. Ide-ide cemerlang Khaldun di dunia pendidikan, berikut metode yang ditawarkannya yang bersifat global dan holistik, masih terus dipergunakan sampai saat ini, sekali lagi menjadi bukti nyata bahwa Ibnu Khaldun adalah pemikir besar sepanjang sejarah.

Kata Kunci : Gagasan Pendidikan, Filsafat Pendidikan

\section{Ibnu Khaldun}




\section{A. Pendahuluan}

Pemikiran Ibnu Khaldun merupakan ide-ide pemikiran pendidikan yang masih aktual sampai hari ini. Pemikiran pendidikannya bukan sebagai suatu aktifitas yang semata-mata bersifat pemikiran dan perenungan yang jauh dari aspekaspek pragmatis di dalam kehidupan. Melainkan pemikirannya tentang pendidikan merupakan fenomena nyata yang lahir dari terbentuknya masyarakat dan perkembangannya dalam tahapan kebudayaan.

Menurut Khaldun, pendidikan tidak pernah mengenal batas usia, tempat dan waktu. Hal ini karena pada hakekatnya manusia akan selalu berpikir, berkreasi dan beraktifitas untuk dapat mencapai tujuan-tujuan kehidupan yang ingin diraih dengan cara-cara dan metode tertentu. Maka selama tujuan-tujuan hidup (kebahagiaan dunia dan akhirat) tersebut belum tercapai, makhluk manusia akan terus melakukan proses pendidikan dan pembelajaran (Long life education).

Ibnu Khaldun merupakan sosok yang tulus dan rendah hati.
Berangkat dari uraian di atas, secara implisit Khaldun ingin menyatakan bahwa apapun yang dihasilkan oleh pemikirannya tentang pendidikan dapat saja berubah seiring fenomena realitas masyarakat yang terus berkembang. Oleh karena itu, bila pada kenyataannya pemikiranpemikiran Khaldun masih terus memberi inspirasi dalam dunia pendidikan sekarang, maka hal ini semakin membuktikan bahwa upaya untuk mendeskripsikan pandangan dan ide-ide Ibnu Khaldun tentang falsafah pendidikan menjadi satu hal yang urgen untuk terus diketahui terutama bagi para orang tua dan guru atau siapa saja pun yang terjun di lapangan pendidikan.

\section{B. Metode Penelitian}

Jenis penelitian ini adalah penelitian kepustakaan. Metode yang digunakan adalah metode content research yaitu menjadikan karya monumental Ibnu Khaldun: The Muqaddimah sebagai referensi utama dan beberapa buku pendukung lainnya.

Analisis data yang dipergunakan adalah teknik analisa data kualitatif 
ISSN 1979-9950 (print) || ISSN 2598-0033 (online), http://jurnal.umsu.ac.id/index.php/intiqad

DOI: 10.30596/intiqad.v12i1.4435

Vol. 12, No. 1 (June 2020)

yaitu analisa data reflektif thinking, yaitu teknik analisa data dengan proses pemikiran hilir mudik. Selain itu juga menggunakan metode komparatif, yaitu meneliti faktor-faktor dengan situasi atau fenomena yang diselidiki dan membandingkan dari satu faktor dengan faktor lain.

\section{Hasil dan Pembahasan}

1. Tujuan Pendidikan Menurut Ibnu Khaldun

Pendidikan menurut Khaldun memiliki pengertian yang luas. Pendidikan tidak dibatasi oleh ruangan kelas dan usia. Oleh karena itu, siapa saja yang tidak terdidik secara pendidikan formal oleh guru ataupun orang tuanya di dalam rumah tangga, maka akan terdidik oleh zaman. Maksudnya bila seseorang tidak memperoleh pendidikan seperti tata krama atau akhlak yang dibutuhkan sehubungan pergaulan bersama melalui guru-guru dan para orang tua, maka ia akan mempelajarinya dengan bantuan alam, dari peristiwa-peristiwa yang terjadi sepanjang zaman. Maka setiap peristiwa dalam kehidupan akan menempa jiwa dan menjadi momentum pengajaran serta pendidikan bagi orang tersebut.

Pendidikan bukan hanya merupakan proses belajar mengajar yang dibatasi oleh empat dinding, dan satu atap. Melainkan pendidikan adalah suatu proses, di mana manusia secara sadar mampu menangkap, menyerap, dan menghayati peristiwaperistiwa alam sepanjang kehidupannya.

Ibnu Khaldun secara tersirat di dalam Muqaddimah menjelaskan tentang tujuan pendidikan. Hal ini dinyatakan oleh Abdul Rahman anNahlawi, yaitu:

a. Tujuan peningkatan pemikiran

Ibnu Khaldun memandang bahwa salah satu tujuan pendidikan adalah memberikan kesempatan kepada akal untuk lebih giat dalam melakukan aktivitas. Hal ini dapat dilakukan melalui proses menuntut ilmu dan keterampilan. Dengan menuntut ilmu dan keterampilan, seseorang dapat meningkatkan kegiatan potensi akalnya. Disamping itu, melalui potensinya, akal akan mendorong manusia untuk memperoleeh dan melestarikan pengetahuan. Melalui proses belajar, manusia senantiasa mencoba meneliti 
ISSN 1979-9950 (print) || ISSN 2598-0033 (online), http://jurnal.umsu.ac.id/index.php/intiqad

DOI: 10.30596/intiqad.v12i1.4435

Vol. 12, No. 1 (June 2020)

pengetahuan-pengetahuan

atau

informasi-informasi yang diperoleh oleh pendahulunya.

b. Tujuan

peningkatan

kemasyarakatan

Dari segi peningkatan kemasyarakatan, Ibnu Khaldun berpendapat bahwa ilmu dan pengajaran adalah lumrah bagi peradaban manusia. Ilmu dan pengajaran sangat diperlukan untuk meningkatkan taraf hidup manusiake arah yang lebih baik. Semakin dinamis budaya suatu masyarakat, maka akan semakin bermutu dan dinamis pula keterampilan di masyarakat tersebut.

c. Tujuan pendidikan dari segi kerohanian

\section{Meningkatkan kerohanian} manusia dengan menjalankan praktek ibadat, zikir, khalwat (menyendiri) dan mengasingkan diri dan mengasingkan ddari khalayak ramai sedapat mungkin untuk tujuan ibadah sebagaimana yang dilakukan oleh para sufi (Ramayulis, 2009).

Pendidikan bukan hanya bertujuan untuk mendapatkan ilmu pengetahuan akan tetapi juga untuk mendapatkan keahlian. Khaldun telah memberikan porsi yang sama antara apa yang akan dicapai dalam urusan ukhrawi dan duniawi, karena baginya pendidikan adalah jalan untuk memperoleh rezeki. Maka atas dasar itulah Ibnu Khaldun beranggapan bahwa target pendidikan adalah memberikan kesempatan kepada pikiran untuk aktif dan bekerja, karena dia memandang aktivitas ini sangat penting bagi terbukanya pikiran dan kematangan individu. Karena kematangan berpikir adalah alat kemajuan ilmu industri dan sistem sosial.

Ibnu Khaldun menganut prinsip keseimbangan. Dia ingin anak didik mencapai kebahagiaan duniawi dan sekaligus ukhrawinya kelak. Berangkat dari pengamatan terhadap rumusan tujuan pendidikan yang ingin dicapai Ibnu Khaldun, secara jelas kita dapat melihat bahwa ciri khas pendidikan Islam yaitu sifat moral religius nampak jelas dalam tujuan pendidikannya, dengan tanpa mengabaikan masalah-masalah duniawi. Sehingga secara umum dapat kita katakan bahwa pendapat Ibnu Khaldun tentang pendidikan telah sesuai dengan prinsip-prinsip 
ISSN 1979-9950 (print) || ISSN 2598-0033 (online), http://jurnal.umsu.ac.id/index.php/intiqad

DOI: 10.30596/intiqad.v12i1.4435

Vol. 12, No. 1 (June 2020)

pendidikan Islam yakni aspirasi yang bernafaskan agama dan moral.

\section{Pandangan Ibnu Khaldun mengenai Kurikulum dan Materi Pendidikan}

Materi ajar adalah merupakan salah satu komponen operasional pendidikan, maka dalam hal ini Ibnu Khaldun telah mengklasifikasikan ilmu pengetahuan yang banyak dipelajari manusia pada waktu itu menjadi dua macam (Rosenthal, 1967) yaitu:

a. Ilmu-ilmu Filsafat (Aqliyah)

Ilmu ini bersifat alami bagi manusia, yang diperolehnya melalui kemampuannya untuk berfikir. Ilmu ini dimiliki semua anggota masyarakat di dunia, dan sudah ada sejak mula kehidupan peradaban umat manusia di dunia. Menurut Ibnu Khaldun ilmuilmu filsafat (aqliyah) ini dibagi menjadi empat macam ilmu yaitu: 1). Ilmu logika, 2). Ilmu fisika, 3). Ilmu metafisika dan d. Ilmu ukur.

b. Ilmu-ilmu tradisional dan konvensional (Naqliyah)

Ilmu naqliyah adalah yang bersumber dari Alquran dan Hadis yang dalam hal ini peran akal hanyalah menghubungkan cabang permasalahan dengan cabang utama, karena informasi ilmu ini berdasarkan kepada otoritas syari'at yang diambil dari Alquran dan Hadis.

Adapun yang termasuk ke dalam ilmu-ilmu naqliyah adalah semua ilmu yang terkait dengan Alquran dan Hadis seperti: ilmu tafsir, ilmu qiraat, ilmu Hadis, ilmu ushul fiqh, ilmu fiqh, ilmu kalam, ilmu tasawuf, dan ilmu ta'bir mimpi.

Kelompok ilmu-ilmu naqliyah menurut Khaldun membutuhkan ilmu alat atau instrument untuk dapat menggali apa yang terkandung dalam Alquran dan hadis yaitu Ilmu Bahasa Arab. Sedang kelompok ilmu aqliyah memerlukan ilmu alat yang disebut ilmu logika. Kedua ilmu pendukung ini menurut Ibnu Khaldun sebaiknya dipelajari sekedar kebutuhan yakni untuk dapat membantu seseorang memahami ilmu-ilmu pokok; ilmu naqliyah dan ’aqliyah. Maka pembahasan dan diskusi kedua ilmu alat ini sebaiknya tidak terlalu panjang dan mendetail sehingga dapat menghilangkan tujuan mempelajarinya sebatas fasilitas untuk dapat sampai pada ilmu-ilmu pokok. 
INTIQAD: JURNAL AGAMA DAN PENDIDIKAN ISLAM

ISSN 1979-9950 (print) || ISSN 2598-0033 (online), http://jurnal.umsu.ac.id/index.php/intiqad

DOI: 10.30596/intiqad.v12i1.4435

Vol. 12, No. 1 (June 2020)

Demikian pandangan Ibnu

Khaldun tentang materi ilmu pengetahuan yang menunjukkan keseimbangan antara ilmu Naqliyah dan ilmu 'Aqliyah (filsafat).

\section{Pandangan Ibnu Khaldun}

\section{tentang Metode Pembelajaran}

Pandangan Ibnu Khaldun tentang metode pembelajaran merupakan bagian dari pembahasan pada buku Muqaddimah. Metode yang dipergunakan bukan hanya metode mengajar bagi pendidik, melainkan juga metode belajar yang harus digunakan oleh anak didik. Hal ini sebagaimana telah dibahas Ibnu Khaldun dalam buku Muqaddimahnya.

\section{a. Metode mengajar bagi pendidik}

Ibnu Khaldun berpendapat tidak cukup seorang guru hanya membekali anak dengan ilmu pengetahuan saja agar mereka menjadi orang yang berilmu pengetahuan yang menambah pengetahuannya dalam belajar. Akan tetapi juga guru wajib memperbaiki metoda dalam penyajian ilmu kepada anak didiknya; dan hal itu tidak akan sempurna kecuali dengan terlebih dahulu mempelajari hidup kejiwaan anak dan mengetahui tingkat-tingkat kematangannya serta bakat-bakat ilmiahnya sehingga ia mampu menerapkan sesuai dengan tingkat pikiran mereka.

Menurut beliau guru harus mengetahui metode yang efektif dalam mengajarkan materi ajar. Metode yang efektif dalam mengajar adalah dengan cara berangsur-angsur dan sedikit demi sedikit. Langkahlangkah pembelajaran itu adalah sebagai berikut:

Pertama: Dalam memberikan pengetahuan kepada anak didik, pendidik hendaknya memberikan problem-problem pokok yang bersifat umum dan menyeluruh, dengan memperhatikan kemampuan akal anak didik.

Kedua: Setelah pendidik memberikan problem-problem yang umum dari pengetahuan, baru pendidik membahasnya secara lebih detail dan terperinci. Pendidik memberi penjelasan, memberi komentar tetapi belum memberi kesimpulan. Pada tahap ini pendidik dapat menyebutkan berbagai pendapat berbeda terkait satu subjek atau topik bahasan, sehingga siswa memiliki 
ISSN 1979-9950 (print) || ISSN 2598-0033 (online), http://jurnal.umsu.ac.id/index.php/intiqad

DOI: 10.30596/intiqad.v12i1.4435

Vol. 12, No. 1 (June 2020)

wawasan dan juga bahan

pertimbangan.

Ketiga: Pada langkah ketiga ini pendidik menyampaikan pengetahuan kepada anak didik secara lebih terperinci dan menyeluruh, dan berusaha membahas semua persoalan bagaimapaun sulitnya agar anak didik memperoleh pemahaman yang sempurna, tidak ada bahan yang terlewatkan dari penjelasan, tidak menyisakan pertanyaan atau konflik di benak siswa (Rosenthal, 1967).

Pandangan Ibnu Khaldun ini kelak pada abad ke-20, seiring dengan psikologi belajar kontemporer yang kita kenal dengan psikologi gestalt yang antara lain diusung oleh Wolfgang Kohler pada tahun 1912 di Jerman. Psikologi ini menyimpulkan bahwa dalam mempelajari sesuatu, jiwa cenderung pada satu bentuk totalitas secara keseluruhan dan global, bukan yang rigid dan parsial.

Tiga langkah Khaldun dalam penyampaian materi ajar di atas juga sesuai dengan teori yang dikeluarkan oleh Kohlerberg tentang usia kematangan kognisi seseorang mempengaruhi kemampuannya menerima sesuatu. Oleh karena itu,
Ibnu khaldun sangat menekankan pemberian materi ajar yang mudah dicerna sesuai dengan perkembangan usia siswa.

Di samping metode dalam penyampaian pelajaran, Ibnu Khaldun juga menyebutkan beberapa hal yang seharusnya tidak dilakukan pendidik di kelas, yaitu:

1) Tidak memberikan pertanyaan di luar kemampuan murid menjawabnya, dari segi tingkatan usia, kelas maupun buku yang dipelajarinya.

2) Tidak memberi jarak atau jeda panjang dalam pembahasan satu topik yang sama, sebab murid mungkin saja lupa.

3) Tidak mencampur adukkan antara dua disiplin ilmu dan atau dua materi yang berbeda sebelum murid menguasai salah satunya dengan sempurna.

4) Tidak berlaku kasar dalam pemberian hukuman apalagi pada siswa yang masih kecil. Beliau bahkan mengharamkan tindak kekerasan menyakiti siswa sebagai hukuman sebab menurut beliau hal tersebut dapat dicontoh menjadi kebiasaan buruk bagi 
ISSN 1979-9950 (print) || ISSN 2598-0033 (online), http://jurnal.umsu.ac.id/index.php/intiqad

DOI: 10.30596/intiqad.v12i1.4435

Vol. 12, No. 1 (June 2020)

siswa yang juga akan berlaku kasar karena mengimitasi tindakan buruk gurunya atau orang tuanya (Rosenthal, 1967).

Dalam hal metode belajarmengajar, Ibnu Khaldun mengkritisi metode hapalan yang sudah sejak lama diterapkan pada semua institusi pendidikan Islam dari era klasik bahkan sampai zaman modern sekarang ini. Metode hapalan menurut beliau membuat anak didik kurang mendapatkan pemahaman yang benar. Ali alJumbulati menyimpulkan bahwa Khaldun menentang metode verbalisme (ceramah) dalam pengajaran dan menghindari dari hapalan yang tidak memahami sesuatu yang dapat dibuktikan melalui panca indra dari bahan pelajaran yang dihapal anak. Karena menghapal dengan cara demikian ini akan menghambat kemampuan memahami. Beliau mencela guruguru yang terlalu berpegang pada metode verbalistik dan metode mendengar, karena mengajar dengan metede ini tidak akan memberi kesan ke dalam pikiran murid (al-Jumbulati, 2002).
Ibnu Khaldun menyebutkan keutamaan metode diskusi. Beliau secara berulang sering menekankan penggunaan metode ini karena dengan metode ini anak didik telah terlibat dalam mendidik dirinya sendiri dan mengasah otak, melatih untuk berbicara, disamping mereka mempunyai kebebasan berpikir dan percaya diri. Dengan kata lain metode ini dapat membuat anak didik berpikir reflektif dan inovatif. Satu hal yang menunjukkan kematangan berpikir Ibnu Khaldun, adalah prinsipnya bahwa belajar bukan penghapalan di luar kepala, melainkan pemahaman, pembahasan dan kemampuan berdiskusi. Karena menurutnya belajar dengan berdiskusi akan menghidupkan kreativitas pikir anak, dapat memecahkan masalah dan pandai menghargai pendapat orang lain, disamping dengan berdiskusi anak akan benar-benar mengerti dan paham terhadap apa yang dipelajarinya (Rosenthal, 1967).

Metode lain yang mendapat kritik dari Ibnu Khaldun adalah metode pembelajaran matan dan 
ISSN 1979-9950 (print) || ISSN 2598-0033 (online), http://jurnal.umsu.ac.id/index.php/intiqad

DOI: 10.30596/intiqad.v12i1.4435

Vol. 12, No. 1 (June 2020)

syarahnya yang pada waktu itu dikenal dengan sebutan metode iqtisar atau ringkasan. Para pelajar tidak mempelajari ilmu langsung dari kitab aslinya melainkan lewat buku-buku iqtisar ulama yang sudah lebih dulu membaca kemudian meringkasnya berdasarkan pemahaman bacaannya dari sumber asli tersebut. Metode ini dianggap buruk oleh Khaldun karena membuat pelajar pemula bingung disuguhi hasil akhir (kesimpulan) suatu disiplin ilmu tanpa ia mempersiapkan diri untuk menerima ilmu tersebut lebih dahulu.

Disamping metode yang sudah disebut di atas Ibnu Khaldun juga menganjurkan metode rihlah. Rihlah artinya perjalanan untuk menemui guru-guru yang mempunyai keahlian khusus dan belajar kepada tokoh-tokoh ulama dan ilmuan terkenal (al-Jumbulati, 2002). Perjalanan semacam ini telah dilakukan oleh umat Islam sejak masa-masa generasi Islam yang pertama. Dan memang situasi memaksa mereka untuk melakukan hal itu sejak masa permulaan Islam, sebab para ulama Islam dari kalangan sahabat-sahabat nabi ketika itu telah tersebar di daerahdaerah yang telah dibebaskan, tidak lama sesudah pembebasan negerinegeri itu dari kekuasaan asing. Di sana mereka memberi pelajaran kepada rakyat mengenai masalahmasalah agama dan mengajarkan Alquran kepada mereka dan meriwayatkan hadis-hadis nabi. Masing-masing mereka mendirikan pusat ilmu pengetahuan pada masing-masing negeri di mana mereka berada (Shalabi, 1973).

Menurut Ibnu Khaldun perjalanan jauh untuk menuntut ilmu sangatlah berfaedah, sebab manusia dapat mengambil dan mempelajari ilmu pengetahuan dan akhlak dengan dua cara; pertama, dengan mengetahui sendiri, mengajarkan dan memberikannya kepada orang lain, kedua, dengan mencontoh atau dengan diajarkan oleh orang kepada kita secara langsung. Akan tetapi tertanamnya pelajaran pada jiwa dan melekatnya pada pikiran kita adalah lebih kokoh dan lebih kuat, bila pelajaran 
ISSN 1979-9950 (print) || ISSN 2598-0033 (online), http://jurnal.umsu.ac.id/index.php/intiqad

DOI: 10.30596/intiqad.v12i1.4435

Vol. 12, No. 1 (June 2020)

itu diajarkan dengan langsung oleh seorang guru kepada kita. Dengan perjalanan jauh itu kita dapat belajar pada guru-guru yang banyak, dan dengan banyaknya guru-guru itu akan tertanamlah pelajaran itu pada jiwa dan akan melekatlah dia pada pikiran kita dengan kokoh dan kuat. Maka Ibnu Khaldun mendorong mahasiswa agar melakukan perlawatan untuk menuntut ilmu karena dengan cara ini para pelajar dan mahasiswa akan dengan mudah mendapat sumber-sumber pengetahuan yang banyak sesuai dengan tabiat eksploratif penuntut ilmu (Rosenthal, 1967).

Pendidikan modern sekarang memperkuat pandangan Khaldun ini dengan memberi siswa program belajar lewat kegiatan widya-wisata sebagai sarana yang sangat besar artinya dalam upaya mendapatkan pengetahuan langsung di lapangan. Metode rihlah ini dapat juga disamakan dengan metode observasi pada masa sekarang ini (Setiawan, 2015).

Satu metode mengajar sekaligus juga materi ajar yang disetujui dan dianggap sangat baik oleh Ibnu Khaldun seperti dijelaskannya dalam Muqaddimah. Metode ini menurut hemat penulis sangat sesuai dengan apa yang kita sadari sekarang sebagai sekolah rumah (homeschooling). Tipe sekolah seperti ini berikut alternatif kurikulumnya disarankan oleh Khalifah Harun ar-Rasyid untuk diajarkan kepada putranya al-Amin lewat guru istana yang bernama Khalaf bin Ahmar. Metode itu sebagaimana tercantum dalam Mukaddimah: Khalifah ar-Rasyid berkata kepadaku: "Wahai Ahmar, pemimpin agama ini telah mempercayakan anaknya kepadamu, ia adalah kehidupanku dan belahan jiwaku. Rengkuhlah ia dan buatlah ia percaya padamu. Ambillah posisiku dan jadilah seperti orang tua baginya. Ajari ia membaca Alquran. Perkenalkan kepadanya sejarah, biarkan ia mempelajari syair dan ajarkan pula padanya sunnah Nabi. Ajarkan pula ia retorika hingga ia mampu memulai pembicaraan. Laranglah ia tertawa dan suruh ia mempergunakan waktu secara proporsional. Biasakan ia menghormati sanak kerabat saat 
ISSN 1979-9950 (print) || ISSN 2598-0033 (online), http://jurnal.umsu.ac.id/index.php/intiqad DOI: 10.30596/intiqad.v12i1.4435

Vol. 12, No. 1 (June 2020)

mereka berkunjung kepadanya.

Berikan para pimpinan militer tempattempat kehormatan saat mereka mengunjunginya di salon. Jangan biarkan berlalu waktu tanpa sempat kau ajarkan sesuatu yang berguna kepadanya. Lakukan semua itu dengan metode yang tidak menjengkelkannya, yang dapat mematikan pikirannya (aspirasi dan inspirasi). Namun jangan pula terlalu toleran terhadapnya, sebab ia akan bersantai-santai dan bermalasmalas dan terbiasa dengan akhlak seperti itu. Sedapat mungkin, tegurlah ia dengan baik dan lemah lembut. Bila ia tidak mau dengan cara seperti itu, barulah kamu boleh menggunakan kekerasan atau kekasaran.

\section{Metode belajar bagi peserta didik}

Di samping poin-poin yang ditujukan untuk pendidik, Ibnu Khaldun juga memberi tips-tips untuk pelajar dan mahasiswa dengan gaya bahasa yang sangat menarik, menyentuh dan akrab, seolah-olah beliau langsung ada di hadapan kita. Berikut adalah beberapa saran yang dianjurkannya pada para pelajar untuk diingat dalam menuntut ilmu (Rosenthal, 1967):

Pertama, Khaldun mengingatkan bahwa kemampuan berpikir atau daya kognisi adalah merupakan "special gift"; takdir yang istimewa dan hadiah terindah yang diberikan Allah kepada manusia saat ia menciptakan kita. Kemampuan berpikir membedakan manusia dari hewan dan makhluk lainnya. Berpikir berarti awal perintah ke syaraf yang akan menyusun secara seimbang gerakangerakan tubuh. Berpikir juga berarti awal langkah menuju ilmu pengetahuan yang belum diketahui sebelumnya.

Kedua, keterampilan logika adalah pengetahuan tentang cara kemampuan alami manusia untuk berpikir dan memfungsikan pikiran secara spekulatif. Logika memberi gambaran (deskripsi objek) sehingga akal beroperasi secara benar dan akan terhindar dari kesalahan. Logika membantu pencari ilmu untuk menghindar dari jebakan-jebakan pengambilan kesimpulan yang salah. Logika adalah prosedur teknik yang berjalan berdampingan dengan daya kognisi alamiah insan untuk bersamasama membentuk metode yang menunjukkan fungsi akal itu sendiri. Karena fungsinya sebagai prosedur teknik, logika sering kali dapat menyelesaikan masalah. Namun patut 
ISSN 1979-9950 (print) || ISSN 2598-0033 (online), http://jurnal.umsu.ac.id/index.php/intiqad

DOI: 10.30596/intiqad.v12i1.4435

Vol. 12, No. 1 (June 2020)

diketahui ternyata banyak pemikirpemikir besar dunia yang hebat, memiliki hasil prestasi akademis yang membanggakan akan tetapi mereka sebenarnya tidak mempergunakan ilmu logika, apalagi saat orientasi dan tujuan mereka terhadap satu bidang ilmu dilandasi ketulusan dan mereka yakin dengan seyakin-yakinnya akan kasih-sayang Allah yang lebih banyak membantu mereka dalam pencarian kebenaran ilmu. Mereka melanjutkan bahwa dengan bantuan daya kognisi yang alamiah, malah akan menghasilkan yang terbaik sebab Allah sudah menetapkan dalam sunnah-Nya akan fungsi akal yang sudah pasti berguna untuk mendapatkan pengetahuan yang objektif.

Ketiga, di samping modal daya kognisi dan keterampilan logika seperti yang telah dikemukakan di atas, dalam menuntut ilmu para pelajar membutuhkan pengetahuan tentang kata-kata dan metode yang dipergunakan kata-kata untuk mewakili ide-ide yang ada di kepala. Caranya adalah dengan mengambil kata dari bentuk huruf perhuruf yang membentuk kata yang diucapkan untuk masalah ilmu yang diambil dari penulisan dan mengambil pemahaman kata dari ceramah/pembicaraan untuk ilmu yang diambil dari metode ceramah yang disampaikan. Cara pertama adalah usaha memperoleh ilmu pengetahuan lewat pemahaman tulisan, misalnya saat membaca buku pelajaran, makalah, artikel dan lain sebagainya. Cara kedua adalah pemahaman yang diambil dari katakata yang diucapkan seseorang untuk menunjukkan ide-idenya (misalnya dosen atau rekan yang sedang presentasi) yang sedang kita dengar keterangannya dan ingin kita ambil inti pembicaraannya. Kedua cara di atas memerlukan keterampilan logika untuk sampai pada satu deduksi dan daya kognisi untuk mengurai ide-ide yang abstrak.

Tidak semua pelajar dapat dengan mudah mengungkap hijab bahasa atau kata dengan cepat selama masa belajar. Perdebatan dalam diskusi malah sering kali menyebabkan orang berhenti memahami makna kata-kata sulit. Interupsi yang mengganggu jalannya diskusi dan keragu-raguan menyebabkan pelajar terperangkap 
ISSN 1979-9950 (print) || ISSN 2598-0033 (online), http://jurnal.umsu.ac.id/index.php/intiqad

DOI: 10.30596/intiqad.v12i1.4435

Vol. 12, No. 1 (June 2020)

dalam argumen yang tidak objektif.

Maka seringlah berlatih memahami makna setiap kata secara objektif sambil terus berharap semoga Allah akan senantiasa memberi petunjuk dan bimbingan dalam memahamkan pelajaran.

Bila suatu saat pelajar terbentur kesulitan dan hambatan dalam memahami masalah-masalah karena banyaknya keragu-raguan yang mengganggu di kepala, maka lepaskan semua makna, hijab kata-kata dan masalah-masalah yang meragukan. Tinggalkan semua prosedur-prosedur teknik dalam logika dan jangan mengambil realitas yang dimunculkan kemampuan berpikir alamiah. Akan tetapi bebaskan pikiran dan biarkan ia mengalir secara spekulatif seperti yang diinginkan. Dan yakinkan diri bahwa Allah akan membantu.

Pada kenyataannya, persepsi atas sebuah kebenaran akan muncul dari kemampuan alamiah akal yang bebas dari imaginasi dan saat seorang meyakini akan adanya kasih-sayang Allah. Ambillah alur logika sebagai bahan pertimbangan, namun tetap mintalah kemurahan-Nya untuk dapat melintasi kemelut dalam memahami kebenaran ilmu.

Demikian pandangan Ibnu Khaldun tentang berbagai masalah yang berkaitan dengan pendidikan. Dan apabila kita cermati satu demi satu pandangannya tentang kurikulum materi dan metode pendidikan, maka dapat kita tarik suatu kesimpulan bahwa ilmuan yang diakui Barat dan Timur ini memang memiliki pandangan yang jauh ke depan dalam berbagai masalah pengetahuan, berpikir universal dan sintetik, sehingga filsafatnya tentang pendidikan tidak pernah dirasanya usang bahkan banyak diteladani baik kawan maupun lawan.

\section{Simpulan}

Ibnu Khaldun merupakan sosok ilmuwan muslim yang memiliki kontribusi besar dalam perkembangan ilmu pengetahuan pada masanya. Pemikiran-pemikirannya bersifat futuristik dan masih dapat dipergunakan hingga saat ini.

Sosok Ibnu Khaldun diakui keilmuannya baik di dunia Barat maupun Timur, salah satunya adalah terkait dengan pendidikan. Ibnu Khaldun menetapkan tujuan-tujuan pendidikan 
ISSN 1979-9950 (print) || ISSN 2598-0033 (online), http://jurnal.umsu.ac.id/index.php/intiqad DOI: 10.30596/intiqad.v12i1.4435

Vol. 12, No. 1 (June 2020)

yang terbebas dari unsur materialistik, kurikulum yang terintegrasi bahkan metode mengajar dan belajar yang holistik. Pandangan Khaldun ini kelak pada abad ke-20, seiring dengan perkembangan psikologi belajar kontemporer, kita mengenalnya dengan istilah psikologi gestalt yang diperkenalkan oleh Wolfgang Kohler pada tahun 1912 di Jerman.

Tiga langkah Khaldun dalam penyampaian materi ajar juga sesuai dengan teori yang dikeluarkan oleh Kohlerberg tentang usia kematangan kognisi seseorang mempengaruhi kemampuannya menerima sesuatu.

Gagasan lainnya yang bahkan dijadikan trend dalam dunia pendidikan sekarang ini adalah metode belajar study tour (rihlah) dan homeschooling (sekolah rumah) berikut kurikulumnya. Ide-ide cemerlang Khaldun di dunia pendidikan, berikut metode yang ditawarkannya yang bersifat global dan holistik, masih terus dipergunakan sampai saat ini, sekali lagi menjadi bukti nyata bahwa Ibnu Khaldun adalah pemikir besar sepanjang sejarah.

\section{E. Daftar Pustaka}

Al-Jumbulati, A. (2002). Perbandingan Pendidikan Islam. Jakarta: Rineka Cipta.

Ramayulis. (2009). Filsafat Pendidikan Islam. Jakarta: Kalam Mulia.

Rosenthal, F. (1967). Ibnu Khaldun The Muqaddimah. USA: Princeton University Press.

Setiawan, H. R. (2015). Pendidikan dalam Perspektif Pemikiran Ibnu Khaldun. The 8th International Workshop on Islamic Development (S. 34). Medan: UMSU Press.

Shalabi. (1973). Sejarah Pendidikan Islam. Jakarta: Bulan Bintang. 